\title{
A narrative interpretation of the cultural impressions on water of the communities along the Vaal River, Parys, Free State
}

\begin{tabular}{|c|c|}
\hline \multicolumn{2}{|c|}{$\begin{array}{l}\text { Authors: } \\
\text { Tribute J. Mboweni }{ }^{1} \\
\text { Engela P. de Crom }{ }^{1} \text { (1) }\end{array}$} \\
\hline \multicolumn{2}{|c|}{$\begin{array}{l}\text { Affiliations: } \\
{ }^{1} \text { Department of Nature } \\
\text { Conservation, Tshwane } \\
\text { University of Technology, } \\
\text { South Africa }\end{array}$} \\
\hline \multicolumn{2}{|c|}{$\begin{array}{l}\text { Corresponding author: } \\
\text { Engela de Crom, } \\
\text { decromep@tut.ac.za }\end{array}$} \\
\hline \multicolumn{2}{|c|}{$\begin{array}{l}\text { Dates: } \\
\text { Received: } 12 \text { May } 2016 \\
\text { Accepted: } 30 \text { Aug. } 2016 \\
\text { Published: } 31 \text { Oct. } 2016\end{array}$} \\
\hline \multicolumn{2}{|c|}{$\begin{array}{l}\text { How to cite this article: } \\
\text { Mboweni, T.J. \& De Crom, } \\
\text { E.P., 2016, 'A narrative } \\
\text { interpretation of the cultural } \\
\text { impressions on water of the } \\
\text { communities along the Vaal } \\
\text { River, Parys, Free State', The } \\
\text { Journal for Transdiciplinary } \\
\text { Research in Southern Africa } \\
\text { 12(1), a345. http://dx.doi. } \\
\text { org/10.4102/td.v12i1.345 }\end{array}$} \\
\hline \multicolumn{2}{|c|}{$\begin{array}{l}\text { Copyright: } \\
\text { (c) 2016. The Authors } \\
\text { Licensee: AOSIS. This } \\
\text { is licensed under the } \\
\text { Creative Commons } \\
\text { Attribution License. }\end{array}$} \\
\hline \multicolumn{2}{|l|}{ Read online: } \\
\hline 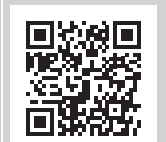 & $\begin{array}{l}\text { Scan this QR } \\
\text { code with your } \\
\text { smart phone or } \\
\text { mobile device } \\
\text { to read online. }\end{array}$ \\
\hline
\end{tabular}

This article is about the significance of the Vaal River for the communities inhabiting the area. Using the interpretation of narratives and rituals, the extent of the connection or disconnection between the communities and the aquatic environment is described. Traditional rituals, religious practices and beliefs associated with the river form an important part of the lives of people living in the area. Results show that industrial development and urbanisation have direct implications not only on the environment but also on the cultural lives and practices of the communities in the areas where these occur. Because of its impact on the environment, development has a direct impact on the people who depend on the environment for both their physical and spiritual well-being. Any form of sustainable development needs to put these factors into consideration for development to truly be sustainable. In addition to forming a part of Environmental Impact Assessment prior to any development, the infringement of the cultural significance and the meanings that local communities have attached to aquatic landscapes should come with stringent legal consequences.

Significance of work: Over the past years, the cultural connection between communities in Parys and the Vaal River area has been influenced by the effects of industrialisation, urbanisation and other anthropogenic factors that stem from these. This study found that there is a range of cultural rituals and beliefs that form part of the everyday lives of many residents of the communities in Parys. The significance of this study lies in recognising the importance of aquatic environments for the cultural health of communities and that, prior to development, developers who aim for sustainable development need to adhere to the National Heritage Resources Act, Act No. 25 of 1999. The Act includes the protection of sites of cultural significance to a community, and this involves the Vaal River. In addition to forming a part of the Environmental Impact Assessment prior to any development, infringement of the cultural significance and the meanings that local communities attach to aquatic landscapes should come with stringent legal consequences. The study also emphasises that it is important to realise that one cannot continue to isolate natural science from social science in debating what is sustainable.

\section{Introduction}

The town of Parys lies on the eastern outskirts of the Vredefort Dome World Heritage Site in the Free State Province of South Africa (Du Pisani 2007). The area is essentially a farming community, but it has become a popular town for day visitors from Gauteng particularly because of its proximity to Johannesburg (Potchefstroom Attractions and Activities 2013). This growth in popularity can be ascribed to second-home development associated with the growth of the tourism industry in Parys and the surrounding environment, which mainly includes the Vaal River and the Vredefort Dome through which the Vaal River runs (Hoogendoorn \& Visser 2004). The Vaal River, therefore, plays a significant role in the lives of the communities living in this area.

It has long been realised that a special bond existed between the ancient peoples of southern Africa and water (Tempelhoff 2008:28). It makes sense, therefore, that human settlements such as those in Parys and its surroundings, develop in areas with dependable supplies of water (Boyd 2000). However, over the past years, the water quality of the Vaal River has been affected by mining, industrial and agricultural processes and more recently by urbanisation and subsequent anthropogenic influences (Ochse 2007). Extensive research has been conducted on the negative health and ecological implications of the pollution of the Vaal River. For example, Tempelhoff et al. (2008:30), found that water users may experience a range of impacts as a result of changes in water quality. The Department of Water Affairs (DWAF) (2009) reported that the entire middle 
section of the Vaal River is regarded as hypertrophic, with phosphate levels exceeding recommended standards. The subsequent corrupt ecological system will influence the cultural health of communities of people resident on the banks of the Vaal River in a negative manner (Tempelhoff et al. 2008:33).

Although research has placed emphasis on the health aspects of people and the ecosystem, little has been documented regarding what the river means in terms of spiritual or emotional well-being for the communities inhabiting the area. The problem, therefore, also outlined by Wadham, Willis and Pearce (2009:1) is that the significance given to the commodification of water and to a lesser extent, the environmental uses of water or environmental flows, overshadow the social significance of water in establishing and maintaining communities. More specifically, the significance of water bodies such as rivers, for the maintenance of cultural practices, is often overlooked.

Using the interpretation of practices such as narratives and rituals, the study for this article was aimed at determining the cultural impressions on water of the communities along the Vaal River.

\section{Methods}

A narrative process was followed in this qualitative research. It allowed the researcher to concentrate on an individuals' experiences, meanings, symbolism and feelings regarding specific events and the unique manner in which individuals express themselves in their own language (Marshall \& Rossmann 1995:87). The target population consisted of inhabitants from the towns of Parys, Tumahole, Schonkenville and the farming areas within the Vredefort Dome. These respondents formed part of the study mainly because they live close to the Vaal River and, therefore, either have personal interactions with the river or know people who interact with the Vaal River. Data were collected between 2012 and 2013 by means of interviews and questionnaires which were recorded and transcribed. Member checks were done to ensure the trustworthiness of the data (Lincoln \& Guba 1985; Roberts, Priest \& Traynor 2006; Shenton 2004). Data reduction was done by means of content analysis (Creswell 2009:183). The sample size was based on information need; hence, the guiding principle in sampling was data saturation (Guest, Bunce \& Johnson 2006), which was achieved after 11 interviews and 213 questionnaires.

\section{Results and discussion}

A total of 224 respondents were recorded, with $56 \%$ being male and $44 \%$ female. The average age of the respondents was between 31 and 40 years (35\%), and the majority of the respondents (55\%) had lived in the study area for longer than 10 years.

Respondents were asked to relate their cultural ceremonies, rituals, beliefs and stories concerning the Vaal River, which they had either experienced themselves or heard of through folklore or tradition. Resulting themes from content analysis are discussed under the following headings: (1) Ceremonies and rituals, (2) Religious practices, (3) Beliefs and (4) Traditional healing.

\section{Ceremonies and rituals}

For the purpose of this article, ceremonies and rituals are classified under one theme and are regarded as 'a sequence of activities involving gestures, actions and objects, performed in a sequestered place (in this case, the Vaal River), and performed according to set sequence' (Merriam-Webster Dictionary 2014).The ritual of collection of water from the Vaal River, which is then used for different ceremonies in the home, is one of the most performed rituals as attested for by the majority of respondents $(85 \%)$. The water is sprinkled around the house to dispel bad spirits. The following statements from respondents confirm this:

'My experience of people along the Vaal River is of a man who had two-litre bottles filled with water from the river, which he said would be used for a ritual of cleansing against a Tokoloshe at home.'

'The water from the river can be used to bathe with or to sprinkle around the house, depending on what a person's problem is. You sprinkle the river water around the house to chase off bad spirits.'

Although water-related rituals are not confined to the river itself, as is evident from the quotes above, some are indeed performed at specific locations next to the river. These include lighting candles or throwing coins into the river to communicate with ancestors. Although there are other cultural groups in Parys, communities in the vicinity of the Vaal River belong predominantly to the Basotho cultural group. They view the river not only as a source of drinking water but also as a spiritual sanctuary where one goes to communicate with the ancestors. The following statements confirm this:

'Before you go into the river, you must throw silver coins into the river and pray. This is called ho kgantsha; translated, this means "shining a light".'

'When you go to the river, you need to light up (ho kgantsha) by throwing in silver coins. ... sometimes you light candles. This opens your path. You are basically praying to the water spirits. We call them our grandmothers and grandfathers.'

The concept of using water from rivers for cultural rituals is not unique to the communities near the Vaal River and is certainly not unique to South African cultures. Cultural rituals related to rivers and other bodies of water are practised in many parts of the world. Glass-Coffin (1998:22) observed how traditional healers in Peru capture the evil spirit by sucking the disease from the victim's body, putting it in a special mixture and then spitting this mixture into a flowing river. In the Zionist practice, water plays a crucial role in the expulsion of evil and illness, that is, to remove isimnyama, the dark cloud that envelopes a person and attracts bad luck and attacks by witches (DWAF 2005:10). Although there is 
considerable cultural variation within societies and it is difficult to generalise, many of these practices establish the meaning of water as a 'life-giving' substance that can purify and regenerate (Verouden \& Meijman 2010:21).

In support of these findings, the DWAF (2005:9) confirmed that there are a range of practices that are performed by cultural and religious communities, such as initiation and baptism ceremonies, that involve the use of water from sources such as rivers, streams, dams and springs.

\section{Religious practices}

Religious practicesinclude any ritual, sermon, commemoration or worship (of a deity), sacrifices, festivals or other aspects of the cultures along the Vaal River. In this regard, the majority of the respondents (54\%) associate the river with the religious practice of prayer, followed by baptism (49\%) with the added benefit of being healed of diseases or ill-health. The significance of water in religious uses is closely connected to beliefs and practices in which disease is conceptualised in holistic terms as an imbalance between the physical body and the social, cultural and natural universe (Verouden \& Meijman 2010:22). The following statements from respondents serve as examples in this regard:

'People from the Apostolic Faith Church go to the river to pray and get baptised with the belief that the problems that they have will go away.'

'When you go to the river, you go in to baptise people. A person will come here when they are sick; you pray for that person to see [or be shown] if you should take them to the river. It is important that when the person returns from the river, by their faith not yours, they come out healed.'

This corresponds with Holland's (2005:xvi) view that far from being confined to a church or mosque once a week, the traditional African's religion embraces his whole environment. Considering rivers as sacred bodies is, however, not unique to African culture. For example, the river Ganga (otherwise known as the Ganges River) occupies a unique position in the cultural ethos of India. According to Sharma (1997:1), from ancient times the Ganga has been India's river of faith, devotion and worship, and millions of Hindus accept its water as sacred. Even today, people carry treasured Ganga water all over India and abroad because it is 'holy' water and known for its 'curative' properties (Sharma 1997:1).

The above demonstrates that communities in many parts of the world, including the Vaal River, are connected with their aquatic environment through a variety of religious practices. These practices have a spiritual and an aesthetic significance in their lives. According to Swarup (2011:25), the river Narmada, one of the seven holiest rivers in India, is said to have originated from the tears of Lord Shiva, and it is believed that each stone embedded in the river is considered to be a Shiva Linga, a representation of Lord Shiva. The whole atmosphere along the banks of the Narmada River is engrossed in Shiva worship (Swarup 2011:25).
As in the case of the Vaal River, the location of a river and its association with holy beings in certain cultures is principally what results in the worship practices that are carried out at rivers.

\section{Beliefs}

In addition and closely related to religious practices, the respondents alluded to other cultural beliefs associated with the Vaal River and more than a third indicated that what connect people to the river is the faith and belief that the river has properties which are beneficial to their general well-being. Strang (2004:5) states that interactions with water take place within a cultural landscape which is the product of specific social, spatial, economic and political arrangements, cosmological and religious beliefs, knowledge and material culture, as well as ecological constraints and opportunities.

Respondents near the Vaal River believe that there are living beings in the river. One popular belief is that of the 'river snake', mentioned by more than a third of all respondents. The following statement serves as an example reference to the river snake:

'I have heard people say that in the Vaal River there is a snake, especially since it is a river that does not dry up. If you have amadlozi [ancestral calling], if you go into the river for rafting or fishing, the snake might take you and if your family cries saying that you have drowned, the snake will not release you.'

According to another respondent, it is not often that people see the water snake:

'There are certain people who can see it. You cannot just see it face-to-face. If you see it, that may be the end of you. The snake has specific places where it passes. It has its time to show and its place where it lives; the evidence is in how the water is. You can see that something was happening there because the water looks like it was stirred.'

In addition to the water snake, believed to be a living creature, a number of respondents also believe that the flow of the river itself is 'alive' and as such has healing properties. Water animism is based on a belief that natural objects (such as river water, lakes and springs) are alive and possess souls (DWAF 2005:13). The following serve as example of what was mentioned:

'Even with the river water that [is flowing all the time], you make someone bathe in that water, which has been prayed for, and they will be healed.'

'The river being alive depends on people's faith. Culturally, we know and believe that there is life in the flowing river.'

'We have faith that when a person has been dipped in the water, the pain will leave them - the life in the water will take it up.'

Rinne (2001:52) confirms these findings and says that flowing water is regarded as the most pure water, and thus, flowing water is considered suitable for holy and healing practices, as indicated by respondents along the Vaal River. 


\section{Traditional healing}

The practice of traditional healing was mentioned by the majority of respondents $(84 \%)$ who indicated that they know the Vaal River is used for the training of and practices by traditional healers. The following statements support the above:

'In terms of traditional healing, sometimes a person can get a vision of the river, meaning that they need to be trained in the river for them to become a traditional healer.'

'When they are taken to the river by someone with the knowledge, they go into the portion of the river according to what they have been shown in the dream or vision. When you are a traditional healer trained in the river, you can go into the river with them and can even spend up to thirty minutes in the river, underwater.'

A farm worker whose aunt trained in the river to become a traditional healer, said:

'She woke up 1 day and disappeared. After a few days, through dreams, we then knew that she was in the river. In those dreams, we were also informed about the kind of cow to bring in order for her to be released. You have to do what you are told so that the person does not remain in the river forever.'

The practice of traditional healing is not unique to South Africa or the Parys, Vaal River area. It forms an important part of many African communities. The World Health Organization estimates that up to $80 \%$ of the population in Africa makes use of traditional medicine (Richter 2003:10). DWAF (2005) reported that during the initiation of traditional healers, apprentices are required to stay at the river for a number of days, during which time they constantly bathe in the stream of the river and are introduced to the river spirits. African traditional healers also collect the water from the rivers and streams because they are believed to possess healing powers from the spirits residing in them.

Traditional healers play an influential role in the lives of African people and have the potential to serve as crucial components of a comprehensive health care strategy (Richter 2003:10). As indicated from respondents in this study, water is regarded as an essential element in traditional healing, both practically and symbolically, a finding supported by Steinglass (2001:32).

\section{The meaning of cultural rituals, practices and beliefs}

In studies examining sources of meaning, experiences in nature have emerged as a significant category for adults (O'Connor \& Chamberlain 1996; Reker \& Woo 2011). Possibly, those who are strongly nature-connected derive a sense of meaningful existence from their closeness with nature (in this case the Vaal River) and this, in turn, boosts wellbeing (Howell, Passmore \& Buro 2012:3). Thus, the meanings engendered by experience (in nature) are simultaneously part of the cultural landscape that every person enters and exits over their lifetime (Strang 2004:67). In the case of the
Vaal River area, more than $50 \%$ of the respondents have lived for over 10 years in the area. As a result, they have had experiences that connect them to the river, experiences that form part of their everyday lives and ultimately, their culture and the meaning they assign to the river, aspects evident from the quotes provided. Evidently, the river bears a meaning beyond the utilitarian use to the residents of this area. Ultimately, the river bears the meaning of life itself, or maybe more accurately, the presence or absence thereof. For example, a muti-shop owner in Parys attests to the notion of water as life:

'Water is life. We live through the water. Life is there [in the river]. You can go anywhere ... without water, you will not live.'

According to Bouguerra (2006:14), there are innumerable symbolic meanings attached to water in the traditions and cultures of the African continent. The narratives outlined in this article not only reveal the people's perspectives on certain aspects of their immediate environment, in this instance, their aquatic environment, but they also house within them the deep-rooted cultural meanings associated with this environment. Although the different African communities tend to differ in language and ways of life, spiritual and cultural practices form an important part of these communities. It forms an important part of their belief system that often guides not only their way of life but also their moral standing, which often includes the way in which they interact with their environment (Holland 2005). This is also true for the respondents in the study area. Generally, those who conduct rituals at the river view it as a sacred place where their ancestors and the highly feared and respected water snake reside. As a result, the river is respected. For example, it is believed that showing disregard to the water snake and the environment in which it is found may result in unfortunate events. The following statement serves as example of this belief:

'When a bridge was built across the Vaal River, a lot of white people got injured. They wanted to direct the snake to the one side for it to pass at [the time they wanted to build the bridge]. They even used explosives to move it so they could build [the bridge]. It never happened in the way they wanted and many died ...'

The following section examines the factors that threaten cultural rituals, beliefs and practices.

\section{Threats to the water-related cultural rituals, practices and beliefs}

In any setting, a variety of factors can prevent people from using water bodies. In this case, respondents regarded pollution as the single most important threat to them being able to use the river and commented as follows:

'The river has been badly tampered with and polluted, leading to infected fish and difficulty in use for rituals.'

'The one thing that affects people the most is the fact that when we go to the river, we find the water polluted. We cannot take the water home for anything. We cannot eat the fish. Things cannot be right this way. In other places, the water is mixed with sewage. How can you use water which has been mixed with sewage?' 
'The water is dirty. We cannot use it for anything. This affects us all. We get cholera from the dirty water.'

Although the availability of water is important, the quality thereof is of even more importance to humans (Clarke 2002). Thus, it is unsurprising that water issues such as pollution create enormous anxiety. Mining and other economic activities have led to the pollution of the Vaal River with metals of mainly industrial origin (Pheiffer et al. 2014:117), coupled with upstream faecal matter (Khakibos 2013). According to Taylor (2014) the Gauteng Department of Agriculture and Rural Development launched a 5-year plan in 2012 to deal with the problem. Moolman (2012) reported that government is implementing a short-term solution to acid mine drainage (AMD) through neutralisation - a process of treating the AMD with lime, neutralising its acidity - but that this process does not sufficiently remove sulphates, which means the water remains unfit for human consumption. Comments from respondents with regards to unsuccessful intervening in the ongoing pollution issues include the following:

'Mostly, the one thing that makes the people angry is the fact that when we go to the river, we find the water always polluted. In other places, the water is mixed with sewage. Companies dump their waste in the river, and the government is doing nothing to stop it.'

'The water in the river is not clean and this affects business. No one is doing anything to stop the illegal dumping of waste and sewage into the river. Sometime during the year [2013], clients from Johannesburg who had booked to raft said that they did not want to raft anymore because they had heard about the Vaal River being polluted.'

From the abovementioned discussion, it is evident that the health of an aquatic environment has an impact on the practice of water-related cultural rituals as well as the general health of the communities living near it. Throughout history, the use of water has reflected various experiences and their interpretations as well as values regarding health, illness and well-being (Verouden \& Meijman 2010:19). The National Water Resource Strategy, Draft 1 (2002), states:

Resource-directed measures will look at the quality of water, quantity of water, the animals that live in the water resource, and the vegetation [plants] around the water resource. All these must be healthy for the water resource to function properly and to provide water.

Therefore, one can conclude that threats to water resources are threats to the well-being, both physical and spiritual, of those who depend on the water resource. This realisation could provide guidelines that will use culture as an ally to current and future development. However, it is important to outline the significance of these cultural meanings in development.

\section{Significance of cultural meanings}

Holland (2005:xv) states that the traditional belief system is ultimately a study of the people themselves in all the intricacies of traditional and modern life. As such, it ought to be factored into economics and education because ignorance of African beliefs perpetuates misunderstanding of African problems and responses. Without the knowledge of waterrelated cultural practices and their contribution towards the well-being of communities, as well as knowledge of the environment itself, development will forever be misplaced because it will not be serving the very people that it aims to serve.

Over many years of human evolution, communities have developed local skills and often traditional or indigenous techniques for safeguarding aspects of their intangible cultural heritage (South African Heritage Resource Agency 2006). Respondents in this regard describe this viewpoint:

'I think we must keep telling these cultural stories because through the years, they just get lost. We must keep on with that tradition. We need to talk to the old people and document these things.'

'In the olden days when cultural practices were mentioned, people knew and believed that there would be a change. Right now, if you tell someone in their youth to go to the river, mostly, they do not believe in it so that aspect of culture is fading. The only people who still do practise these water rituals now are older people, traditional healers, prophets and church people.'

Ndoro, Mumma and Abungu (2009:v) point out that African immovable cultural heritage is worthy of interest because it contributes to the understanding of the cultures of the world as proposed by UNESCO's World Heritage List. Therefore, it should be fully represented there in the years to come. However, entire sections of this heritage are at risk, yet they often play a decisive role in the quality of life of the communities who use them or live near them.

Recognising the cultural and religious activities of communities can be a powerful driver for social or economic growth and engender a sense of cultural identity and selfconfidence, all of which have a positive impact on the development and or well-being of a community (DWAF 2005). Myths, faiths and symbols seem to serve another essential cause for the survival of communities, namely protection of the environment (Bouguerra 2006:18).

The traditional knowledge, stewardship and management systems, as well as technologies developed by different peoples, typically reflect the deep relationship between biological and cultural diversity (Johnston 2012:xii). Gouws (2013:vi) states that human's fear associated with drought (too little water), floods (too much water), meteorology (the necessity of water), the role of the supernatural (divining water) and superstition (the water snake stories) is expressed in the interaction between people and this water environment. As a result of industrialisation, the fear stated above now includes fear for people's physical and spiritual health, which is linked to polluted aquatic environments. A regular visitor to the Parys area for recreational purposes said: 
'Rivers are an indicator of how healthy our country is. The bottom line is our rivers are in jeopardy.'

Industrial development has direct implications not only for the environment but also for the lives of the communities in the areas where it occurs. This is also supported by the following quote from a resident:

'Government and the municipality need to do more because the pollution from development ... industry ... affects tourists, locals and businesses in the area.

Intangible cultural heritage in the form of rituals, ceremonies, beliefs and symbols, is a very real and active part of people's lives. Intangible cultural heritage and the protection of the environment are mutually beneficial and should form an important part of impact assessments prior to any development.

\section{Recommendations and conclusion}

There is a range of cultural rituals and beliefs that forms part of the everyday lives of many residents of the communities in Parys. These were found to be well known to people of different cultures living in the area even if they did not practise them. These rituals and beliefs were found to have influence on how the communities in this area interact with the Vaal River. For example, those who believe in the presence of the water snake do not like to engage in recreational water activities such as river rafting for fear of upsetting the snake. In fact, they believe that those who have drowned in the river have been taken by the snake.

The river is seen as a source of life as well as a sacred place where ancestors not only reside but also train people for the important task of being a traditional healer. This has resulted in members of the communities in the area having great respect for the river and its role in their spiritual lives. However, the river is polluted, and this affects the people who use it for cultural rituals and their other needs. An adequate water supply is a key element in the good health and well-being of humans and ecosystems, as well as in social and economic development. However, this alone is not enough. Interactions with members of the Parys communities demonstrated that people need an appropriate level of water quality for their physical and spiritual well-being. Religious practices such as baptism cannot be carried out in a polluted river because of serious health implications. People who depend on the river for household water or fishing cannot use either due to a declining fish population and toxins in the water render both water and fish unfit for human consumption.An effective solution to the pollution of the Vaal River needs to be found and implemented. These tasks need to be implemented and led by government working closely with local community structures. This will ensure that waterrelated cultural practices continue to be practised and that the spiritual health of these communities is kept alive. This means that the intangible cultural heritage of these communities is preserved, and future generations will experience these practices and, in turn, pass them on to the next generation.

The connection between people and the natural environment, especially the aquatic environment, is one that is very often taken for granted. However, this connection has for many years influenced human physical and spiritual health. The connection between people and their natural landscape has also had an influence on where people choose to live. People prefer to settle in areas where they can easily access water for their daily utilitarian use as well as for their spiritual and religious needs. These are basic human needs that should be included in sustainable development goals and be strictly protected by policies.

In the past years, the cultural connection between communities in Parys and the Vaal River area has been influenced by the effects of industrialisation, urbanisation and other anthropogenic factors that stem from these. In recognising the importance of aquatic environments for the cultural health of communities prior to development, developers who aim for sustainable development need to adhere to the National Heritage Resources Act, Act No. 25 of 1999. The Act includes the protection of sites of cultural significance to a community, and this involves the Vaal River. In addition to forming a part of the Environmental Impact Assessment prior to any development, infringement of the cultural significance and the meanings that local communities attach to aquatic landscapes should come with stringent legal consequences. It is important to realise that one cannot continue to isolate natural science from social science in debating what is sustainable and an expected logical outcome.

\section{Acknowledgements}

The authors would like to acknowledge the Faculty of Science of Tshwane University of Technology for financial support to complete this study. They would also like to acknowledge the participants who willingly shared their time and knowledge during the interview process, as well as the assistance of the Parys Museum staff members and research assistants during data gathering sessions.

\section{Competing interests}

The authors declare that they have no financial or personal relationship(s) which may have inappropriately influenced them in writing this article.

\section{Author's contributions}

E.P.d.C. was the supervisor for the study. T.J.M. was responsible for data collection. Both authors were involved in the conceptualisation of the research and for data analysis. Both authors provided equal inputs in the writing of the article. 


\section{References}

Bouguerra, M.L., 2006, Water: Symbolism and culture, Productions 108, Institut Veolia Environment, Paris.

Boyd, C.F., 2000, Water quality: An introduction, Kluwer Academic, Boston, MA.

Clarke, J., 2002, Coming back to earth, Jacana, Pretoria.

Creswell, J.W., 2009, 'Editorial: Mapping the field of mixed methods research', Journal of Mixed Methods Research 3(2), 95-108. http://dx.doi.org/10.1177/ 1558689808330883

DuPisani, J.A., 2007, Cultural heritage plan. Report as part of the integrated management plan, AGES, Potchefstroom.

Glass-Coffin, B., 1998, The gift of life: Female spirituality and healing in northern Peru, University of New Mexico Press, Albuquerque, NM

Gouws, C., 2013, Vestiginglangs die Vaalrivier in die omgewing van die Vredefortkoepel, PhD thesis, Northwest University, Vanderbijlpark, South Africa.

Guest, G., Bunce, A. \& Johnson, L., 2006, 'How many interviews are enough? An experiment with data saturation and variability', Field Methods18(1), 59-82. http://dx.doi.org/10.1177/1525822X05279903

Holland, H., 2005, African magic: Traditional ideas that heal a continent, Penguin Publishers, Johannesburg.

Hoogendoorn, G. \&Visser, G., 2004, 'Second homes and small-town (re)development: The case of Clarens', Journal of Family Ecology and Consumer Sciences 32, 105-114.

Howell, A.J., Passmore, H.A. \&Buro, K., 2012, 'Meaning in nature: Meaning in life as a mediator of the relationships between nature connectedness and well-being', Journal of Happiness Studies14, 1681-1696. http://dx.doi.org/10.1007/s10902 012-9403-x

Johnston, B.R. (ed.), 2012, Water, cultural diversity, and global environmental change: Emerging trends, sustainable futures?, UNESCO-IHP, Paris.

Khakibos, 2013, 'By 2014 Vaal River will be polluted', viewed 19 October 2014, from http://www.khakibos.co.za/by-2014-vaal-river-will-be-polluted/

Lincoln, Y.S. \& Guba, E.G., 1985, Naturalistic enquiry, Sage, Beverly Hills, CA.

Marshall, C. \& Rossman, G.B., 1995, Designing qualitative research, Sage, Thousand Oaks, CA.

Merriam-Webster Dictionary, 2014, Merriam Webster, Springfield.

Moolman, S., 2012, Vaal water deficit expected by 2015, viewed 30 June 2014, from http://www.engineeringnews.co.za/article/vaal-water-deficit-expected-by-2015owing-to-amd-2012-10-12

National Water Resource Strategy, Draft 1, 2002, Parys information - Free state tourism information website, 2011, viewed 23 March 2011, from http://www. freestatetourism.org/about-the-free-state/fezile-dabi-parys/index.html

Ndoro, W., Mumma, A. \& Abungu, G., 2009, Cultural heritage and the law: Protecting immovable heritage in English-speaking countries of sub-Saharan Africa, ICCROM, Rome.

Ochse, E., 2007, 'Seasonal rainfall influences on main pollutants in the Vaal River Barrage Reservoir: A temporal-spatial perspective', M.Sc. dissertation, University of Johannesburg, Johannesburg, South Africa.

O'Connor, K. \& Chamberlain, K., 1996, 'Dimensions of life meaning: A qualitative investigation at mid-life', British Journal of Psychology 87(3), 461-477. http://dx. doi.org/10.1111/j.2044-8295.1996.tb02602.x
Pheiffer, W., Pieters, R., VanDyk, J.C. \& Smit, N.J., 2014, 'Metal contamination of sediments and fish from the Vaal River, South Africa', African Journal of Aquatic sediments and 1 is from . http://dx.doi.org/10.2989/16085914.2013.854732
Science

Potchefstroom Attractions and Activities, 2013, Parys - Free state, viewed 15 May 2015, from http://annesplace.co.za/wp-content/uploads/2013/12/Potchefstroom_Info. pdf

Reker, G.T. \& Woo, L.C., 2011, Personal meaning orientations and psychosocial adaptation in older adults, Sage Open, Thousand Oaks, CA.

Richter, M., 2003, 'Traditional medicines and traditional healers in South Africa', Treatment Action Campaign and AIDS Law Project 17, 4-29.

Rinne, E.M., 2001, 'Water and healing - Experiences from the traditional healers in Ile-Ife, Nigeria', Nordic Journal of African Studies 10(1), 41-65.

Roberts, P., Priest, H. \& Traynor, M., 2006, 'Reliability and validity in research', Nursing Standard 20(44), 41-45. http://dx.doi.org/10.7748/ns.20.44.41.s56

Sharma, Y., 1997, Water pollution control - A guide to the use of water quality management principles, UNEP/WHO, London.

Shenton, A.K., 2004, 'Strategies for ensuring trustworthiness in qualitative research projects', Education for Information 22, 63-75.

South Africa, 1999, National Heritage Resources Act, Act No. 25 of 1999, Government Printing Works, Pretoria.

South Africa, Department of Water Affairs, 2009, Integrated water quality management plan for the Vaal River System: Task 2: Water quality status
assessment of the Vaal River System, Report No. P RSA C000/00/2305/1, assessment of the Vaal River System, Report No. P RSA CO00/00/2305/1,
Directorate: National Water Resource Planning, Department of Water Affairs and Forestry, Pretoria.

South Africa, Department of Water Affairs and Forestry, 2005, A desktop study on the cultural and religious uses of water using regional case studies from South Africa, cultural and religious uses of water using regio
Environmental Evaluation Unit, Cape Town.

South African Heritage Resources Agency, 2006, viewed 12 March 2015, from www. sahra.org.za/download-attachment/1360/

Steinglass, M., 2001, 'It takes a village healer: Anthropologists believe traditional medicine can remedy Africa's aids crisis. Are they right?', Lingua Franca 11(3), 28-39.

Strang, V., 2004, The meaning of water, Berg Publishers, Oxford.

Swarup, A., 2011, Cultural and spiritual value of rivers in Indian context [PowerPoint slides], Madhya Pradesh Bhoj Open University, Bhopal, India.

Taylor, T., 2014, Gauteng's acid mine water time bomb, viewed 2 March 2015, from http://www.iol.co.za/scitech/science/environment/gauteng-s-acid-mine-watertime-bomb-1.1694066\#.VPSF02SucYc

Tempelhoff, J.W.N., 2008, 'Historical perspectives on pre-colonial irrigation in Southern Africa', African Historical Review 40(1), 121-160. http://dx.doi.org/10.1080/ 17532520802249506

Tempelhoff, J.W.N., VanZyl, A., VanRiet, G., Gouws, C., Hardy, J., Jordaan, H. et al., 2008, An investigation into the environmental health of the Vaal River in the vicinity of Parys, North-West University, Vanderbjilpark.

Verouden, N.W. \& Meijman, F.J., 2010, 'Water, health and the body: The tide, undercurrent and surge of meanings', Water History 2(1), 19-33. http://dx.doi. org/10.1007/s12685-010-0019-y

Wadham, B.A., Willis, E.M. \& Pearce, M.W., 2009, 'The cultural relations of water in remote South Australian towns, The future of sociology', 2009 Annual Conference of the Australian Sociological Association, Australian National University, Canberra, December 1-4, 2009, pp. 1-12. 